\title{
DIÁlOGOS POSSÍVEIS: A HIPERMÍDIA E O ENSINO DA LITERATURA NA ESCOLA
}

\author{
POSSIBLES DIALOGUES: HYPERMEDIA AND LITERATURE TEACHING AT SCHOOL \\ Eliana Cristina Scheuer*, Rosemari Bendlin Calzavara ** \\ Universidade do Norte do Paraná - UNOPAR $\left({ }^{*}\right)$ \\ Mestranda em Metodologias para o Ensino de Linguagens e suas Tecnologias \\ E-mail: eliana_srl@hotmail.com \\ Universidade do Norte do Paraná - UNOPAR $\left({ }^{* *}\right)$ \\ Professora do Mestrado em Metodologias para o Ensino de Linguagens e suas Tecnologias \\ E-mail: rosemari.calzavara@unopar.br
}

\begin{abstract}
Resumo
A temática hipermídia tem sido objeto de inúmeras pesquisas, porém nos propomos a investigar a possibilidade de um diálogo entre a hipermídia e o ensino, mais especificamente com relação ao trabalho com a leitura dos textos literários na escola. Organizamos o presente artigo em quatro seções. Na primeira, versaremos sobre competência e comportamento; na segunda, a competência informacional; na terceira, os possíveis diálogos, em sala de aula, entre a hipermídia e o ensino da literatura; por fim, refletimos sobre o papel do professor no processo. Após o estudo realizado, conclui-se que um dos caminhos possíveis para o trabalho em sala de aula, com a leitura, é o professor privilegiar, em sua prática pedagógica, o uso de textos literários, fazendo uso da tecnologia a favor da aprendizagem.
\end{abstract}

Palavras-chave: hipermídia. mediação. ensino. literatura.

\begin{abstract}
The thematic of hypermedia has been the subject of extensive research, but we propose to investigate the possibility of a dialogue between the hypermedia and education, more specifically in regards to working with the reading of literary texts at school. We organize this article in four sections. First, we will talk about competence and behaviour; second, our discussion will be about the informational competence; third, we shall discuss the possible dialogues, in the classroom, between the hypermedia and the teaching of literature. Finally, we reflect on the teacher's role in this process. After the study, the conclusion reached is that one of the possible paths to work in the classroom with reading is for the teacher to favour, in his/hers pedagogical practice, the use of literary texts, making use of technology as a means to learning.
\end{abstract}

Keywords: hypermedia. mediation. teaching. literature. 
"Prefiro meu filho com papel e caneta ao lado de um professor incrível do que na sala mais tecnológica do mundo com um mau professor."

(Salman Khan)

\section{CONSIDERAÇÕES INICIAIS}

Em pleno século XXI, perpetuado pela ciência e tecnologia, recorda-se que tudo começou com o lápis, papel, giz, lousa... Depois, vieram as máquinas de datilografar, os mimeógrafos, as máquinas de xerox e, por fim, os computadores. Imensos no início (anos 40), denominados "ENIAC", pesavam toneladas e chegavam a ocupar um andar inteiro de um prédio, mas ao longo dos anos, eles foram aprimorados, aperfeiçoados, até chegar ao que temos hoje, que praticamente podem ser alocados em nosso bolso (LEVY, 2006).

Isso posto, vemos que, na atualidade, a tecnologia faz parte de nosso dia-a-dia. Atingiu-nos como uma avalanche e envolve a todos (MORAN, 2012). Esse contato vem ocorrendo cada vez mais cedo, tanto que crianças de 3 anos estão dominando o vídeo game, de 5/6 anos têm pleno conhecimento dos jogos de computadores, acima de 9 anos já não conseguem sobreviver sem um celular.

Então, do levantar, pela manhã, até o momento de voltar para cama para o descanso noturno, parece que o tempo em que se permanece longe das novas tecnologias é, talvez, o tempo em que se permanece na escola porque, infelizmente, ela ainda não invadiu as salas de aula, com raras exceções.

Sobre essa questão da tecnologia na escola, pesquisas indicam que há 10 anos, 16\% das escolas tinham computador para uso do aluno e $12 \%$ com acesso à internet. Em 2012, já eram 57\% com micros para uso didático, sendo $52 \%$ deles conectados à internet. Encontra-se dados do Ministério da Educação (MEC) que afirmam que esses recursos devem chegar a todas as escolas nos próximos anos, motivo pelo qual os professores devem estar preparados para usá-los. (SANTOMAURO, 2013, p. 47) 
Ocorre que os recursos tecnológicos não surgem ao toque de uma varinha mágica para resolução dos déficits de aprendizagem na escola. Eles são, sim, ferramentas essenciais para o desenvolvimento de novas formas de ensinar/aprender, sua função é indicar novas possibilidades na mediação do ensino em todas as etapas do aprendizado. Agora, é preciso ter alguém que saiba interagir com essas ferramentas, ou seja, manusear esses instrumentos pedagógicos de forma adequada.

O interessante é que, muitas vezes, o professor até conhece tais instrumentos, pois eles fazem parte da vivência diária. Sua importância está, justamente, no fato deles criarem espaços inimagináveis para a busca da informação e, consequentemente, ampliarem o conhecimento de mundo do educando. Essa fruição da informação, bem como a possibilidade de acesso a múltiplos textos/livros/artigos, pode auxiliar a despertar a criatividade do educando. 0 desafio se instaura numa questão: saber transformar essas múltiplas informações, mesmo que trilhadas por um caminho saltitante, de link em link, em um conhecimento real. Surge aqui a questão de uma educação com qualidade e quem pode auxiliar nesse processo é a figura do professor. Este processo, porém, não é tão simples assim, pois envolve vários fatores, desde

a questão da educação com qualidade, a construção do conhecimento na sociedade da informação, a inclusão, a diversidade humana e social, tão enfática em nosso imenso país, as novas concepções do processo de aprendizagem colaborativa, revisão e a atualização do papel e das funções do professor, a formação permanente deste, a compreensão e a utilização das novas tecnologias, visando à aprendizagem dos nossos alunos e não apenas servindo para transmitir informações. Porém fazendo o uso da informática no e para o ensino, para a educação e para a inclusão. [...] cabe lembrar que este processo de construção não acontece simplesmente disponibilizando o acesso ao aluno do vídeo, do computador e da internet, mas existem vários elementos inter-relacionados que apontam a própria mediação pedagógica (SILVA, 2008).

Adentrar nessa teia, que envolve a tecnologia, o novo papel do docente, a compreensão de como funciona esse contexto, exige uma ação: a ampliação das competências informacionais. Então, é preciso aprimorar tais competências ampliando a forma de partilhar conhecimentos, ao mesmo 
tempo em que, ao falar de algo que conhecemos e acreditamos, o entusiasmo possa atrair, contagiar, estimular e convencer os educandos. Para trilhar esse caminho, necessário se faz ampliarmos o saber sobre o desenvolvimento da competência informacional, foco do próximo item.

\section{COMPETÊNCIA E COMPORTAMENTO}

Caminhar pelos conceitos de competência informacional exige que se discuta a questão do comportamento, visto que são questões intrinsecamente interligadas. Na prática, pode ocorrer de ora uma se sobrepor a outra e vice-versa. Numa tentativa de compreender de que forma isso ocorre, percorre-se estes conceitos iniciando pela definição de "comportamento".

O dicionário Aurélio nos apresenta que etimologicamente, a palavra "comportamento" vem de "comportar + -mento", ou seja, trata-se de uma "maneira de se comportar; procedimento, conduta; conjunto de atitudes e reações do indivíduo em face do meio social; o conjunto das reações que se podem observar num indivíduo, estando este em seu ambiente, e em dadas circunstâncias." Já a palavra "comportar", de comportáre <acumular, reunir>, como verbo transitivo, significa "permitir; suportar; admitir; conter em si; ser composto de;" já como um verbo pronominal tem o sentido de "proceder; portar-se; funcionar; reagir".

Diante das definições acima, entende-se por "comportamento", nesta pesquisa, uma resposta do indivíduo a uma determinada situação; e "comportar" é conter em si conhecimentos para funcionar, reagir às situações que surgem cotidianamente. Confrontamo-nos com a necessidade de buscar também o conceito de competência.

O termo "competência", por sua vez, tem recebido muitos significados ao longo do tempo. Antigamente, quando alguém tinha o poder de julgar, dizia-se que a pessoa era competente para tomar / ter aquela atitude. Atualmente, quando se fala em educar, entende-se que os professores devem estar travestidos de competências e habilidades em todas as atividades desenvolvidas. Trata-se de um termo que está em evidência, ou seja, na moda, logo a falta do seu uso indica que a pessoa está em dissonância com as pesquisas atuais. 
Para aprofundar nossos estudos, vamos recorrer ao Dicionário Interativo da Educação Brasileira. Nele, encontramos que competência é um conjunto de conhecimentos (saberes), habilidades (saber fazer) e atitudes (saber ser). Saberes que estão definidos por Jaques Delors (2010, p.31), como portadores de quatro pilares nos quais estão sustentados a Educação:

1. Aprender a conhecer, combinando uma cultura geral, suficientemente ampla, com a possibilidade de estudar, em profundidade, um número reduzido de assuntos, ou seja: aprender a aprender, para beneficiar-se das oportunidades oferecidas pela educação ao longo da vida.

2. Aprender a fazer, a fim de adquirir não só uma qualificação profissional, mas, de uma maneira mais abrangente, a competência que torna a pessoa apta a enfrentar numerosas situações e a trabalhar em equipe. Além disso, aprender a fazer no âmbito das diversas experiências sociais ou de trabalho, oferecidas aos jovens e adolescentes, seja espontaneamente na sequência do contexto local ou nacional, seja formalmente, graças ao desenvolvimento do ensino alternado com o trabalho.

3. Aprender a conviver, desenvolvendo a compreensão do outro e a percepção das interdependências - realizar projetos comuns e preparar-se para gerenciar conflitos - no respeito pelos valores do pluralismo, da compreensão mútua e da paz.

4. Aprender a ser, para desenvolver, o melhor possível, a personalidade e estar em condições de agir com uma capacidade cada vez maior de autonomia, discernimento e responsabilidade pessoal. Com essa finalidade, a educação deve levar em consideração todas as potencialidades de cada indivíduo: memória, raciocínio, sentido estético, capacidades físicas, aptidão para comunicar-se.

Na educação, este conceito começou a ser utilizado a partir da Lei de Diretrizes e Bases (LDB), de 1996, que propõe um currículo escolar no ensino médio que direcione para o desenvolvimento de competências visando, sobretudo, a formação do aluno para a sua vivência no seio social, mais especificamente preparando-o para interagir no mercado de trabalho. 
Diante disso, retomamos a Teoria das Inteligências Múltiplas de Gardner (1995), que permite ao indivíduo desenvolver suas competências na área em que tiver mais habilidade. $\mathrm{O}$ autor identificou as inteligências linguística, lógico-matemática, espacial, musical, cinestésica, interpessoal, intrapessoal, naturalista e existencial e nos proporcionou vislumbrar possibilidades de aprender a conviver com as diferenças e aprender a avaliar, a partir das diversas habilidades que são desenvolvidas na escola, enriquecendo as formas de ensinar-aprender-ensinar.

$\mathrm{Na}$ área de recursos humanos, o termo tem encontrado um espaço mais amplo, mais diversificado. Nos congressos, conferências, MBAs, etc., fala-se em competências na administração de conflitos, competências na comunicação, na negociação, na tomada de decisões, enfim, trata-se do direcionamento voltado para tomar a decisão mais adequada diante de determinada situação.

No dicionário Didático de Português, o termo "competência" é definido como "conhecimento e/ou capacidade que uma pessoa tem e que a torna capaz de resolver determinados assuntos, ou executar certas tarefas, habilidade, aptidão, idoneidade", ou seja, é competente quem tem capacidade, quem está apto para enfrentar situações e sabe como reagir perante elas. É competente quem tem conhecimentos e habilidades necessárias para atingir resultados exigidos nas mais diversas situações, satisfazendo exigências sócio-política-econômica-cultural e educacional.

No dia-a-dia, quando se fala em competências profissionais, utilizam-se de alguns clichês, algumas vezes, sem ter a dimensão de seus significados como ser competente é ter visão estratégica, ser competente é agregar valor ao produto, ser competente é conhecer o mercado, é ter foco no cliente e tantos outros.

Diante dos conceitos, pode-se dizer que para ser competente é preciso saber buscar. Esta busca de algo pode ser denominada de informação, "o ato ou efeito de informar ou informar-se", ou seja, o indivíduo colhe informações, indaga, investiga, e vai ser capaz de realizar, por si mesmo, um aprender relevante e significante que o torne apto a localizar as fontes de informação, documentando-se e, ao elaborar estas informações, está pronto para transferir conhecimentos e buscar, com autonomia, a resolução de problemas, guiando-se por princípios éticos, na relação 
aprender a aprender. Neste momento, recorremos a Perrenoud (2000, p.15), pois ele liga todos estes conceitos, quando define competência como "uma capacidade de mobilizar diversos recursos cognitivos para enfrentar um tipo de situação".

\section{COMPETÊNCIA INFORMACIONAL}

Hobsbawn (1995) relata as revoluções pelas quais a humanidade passou no século XX. Dentre estas, destaca-se as transformações informacionais determinadas, principalmente, pela internet, visto que ela impulsionou a globalização. Assim, foi possível que uma grande base de dados começasse a ser acessada de qualquer lugar no planeta, base esta que até então seguia cautelosamente, quase que "velada", pois seu acesso era mais restrito, sobretudo no que diz respeitos aos grandes clássicos da literatura. Estes passaram por uma ruptura considerável, de um saber "guardado" em uma biblioteca, por exemplo. Uma vez digitalizado e disponibilizado na rede, passa a ser um saber de fácil acesso.

Nesse sentido, observa-se que o mundo avança numa velocidade estonteante. $\mathrm{O}$ aparelho celular desta semana, na próxima, já pode estar ultrapassado. Com isso, nota-se que somos atropelados por uma avalanche de aprimoramentos tecnológicos que, certamente, estão acompanhados da eficiente e eficaz competência informacional. Ocorre que apenas um seleto grupo a domina e seus membros não medem esforços para que consigam desenvolver o aprendizado de novas habilidades (aprender a aprender), que num ato contínuo e num círculo vicioso os tornam, a cada instante, mais e mais competentes.

Se o termo "informação" é definido, também, como instrução, pode-se dizer que informação é o processo de busca do conhecimento, e buscar informação é um ato de incerteza, uma tentativa de compreensão do mundo e das ações desenvolvidas pelo homem nele. Para adentrar nesta compreensão de mundo, é preciso caminhar pelos termos o que, por que, onde, para que, como, entre tantos outros, e estas ações exigem competência. (MELO e ARAÚJO, 2007).

Competência informacional é como "uma compreensão e um conjunto de habilidades capacitando os indivíduos a reconhecer quando a informação é necessária e a respectiva capacidade de localizar, avaliar e usar efetivamente tal informação" (MELO e ARAÚJO, 2007, p.188). 
Capacidade esta que deve estar relacionada à criatividade e ao desprendimento. Com essas asserções queremos dizer que o ato criativo proporciona a liberdade de utilizar o ser e $o$ saber incorporado ao indivíduo à coragem de partilhar, através do fazer, abrindo, desta forma, novas possibilidades de reinventar a informação. Levy $(1999$, p.40) afirma que quanto mais ativamente uma pessoa participar da aquisição de um conhecimento, mais ela irá integrar e reter o que aprendeu.

Corroboramos com Miranda (2004), no que tange à competência informacional ser necessária a todas as atividades profissionais que de uma forma ou de outra prescindem da informação para o bom desenvolvimento do trabalho, não estando voltada apenas aos profissionais da área de informação:

[...] A informação e o conhecimento sempre fizeram parte do trabalho produtivo, mas agora existe visibilidade, sua importância é reconhecida. Como o conhecimento só pode ser mobilizado pelo trabalhador, pela pessoa humana, inverte-se a lógica. $O$ trabalho deixa de ser o fator algo externo ao trabalhador e volta a ser algo intrínseco a quem o realiza (MIRANDA, 2004, p.113).

A citação acima nos permite inferir que a competência informacional ultrapassou a área limítrofe da Ciência da Informação e da Biblioteconomia e está caminhando ao encontro, ou abrindo-se para outras áreas afins, com isso começa-se a delinear a ideia do aprendizado ao longo da vida, ou seja, a preparação da pessoa como um todo para toda a vida.

No intuito de atrelar os pressupostos teóricos à prática docente, vamos focar na área educacional. Neste caso, as proposições acima podem parecer uma utopia, se as relacionarmos ao projeto educacional idealizado para o Ensino Básico, nas escolas públicas: uma aprendizagem contínua. Trata-se da preocupação com a formação do educando como um todo, justamente por isso, esta forma denomina-se "ensino fundamental", no sentido de ser essencial, básico, o alicerce que dará a sustentação para as demais séries. Trata-se do período em que o discente aprende a buscar novas informações, concretizar seu aprendizado, enfim, trata-se de plantar a semente do "desejo de aprender". 
Nesse contexto, percebe-se que é muito enriquecedor, no desenvolvimento da competência informacional, essa mescla de competências. Elas são adquiridas quando se pré-dispõe a atuar numa perspectiva inter e multidisciplinar, mapeando o uso da competência informacional nas organizações proporcionando, assim, uma visão diferenciada, multifacetada na análise e na transformação de dados, com base nessa diversidade de conhecimentos. $E$, por falarmos em diversidade de conhecimentos, a seguir abordaremos uma das fontes dessa diversidade: a hipermídia.

\section{DIÁLOGOS POSSÍVEIS: A HIPERMIIDIA E O ENSINO DE LITERATURA NA ESCOLA}

Hoje, mais do que nunca, é preciso desenvolver a competência tecnológica, para poder lidar com as diversas mídias. Elas estão presentes em nosso cotidiano, permeiam a interação, auxiliam no processo de construção do conhecimento. Isso posto, o sujeito tem à sua disposição blogs, livros, revistas, vídeos, jornais, tvs (abertas e fechadas), tablets, e-mails, chats, etc. Saber lidar com esta diversidade não é uma tarefa fácil e saber como educar através delas muito menos.

Essas novidades, aperfeiçoadas diariamente, têm provocado um desenvolvimento tecnológico que avança a velocidade da luz, dificultando o acompanhamento de tantas transformações. Mesmo diante desse quadro, é necessário encontrar caminhos para compreender e pensar formas de incorporar essas tecnologias como meio pedagógico.

Mediante ao exposto, considerando que as novas tecnologias não são mais meros recursos para "tornar uma aula diferente" mas, sim, componentes fundamentais da cultura, é preciso repensar sobre a reconstrução da prática (Roesler et all, 2005).

De acordo com Santaella (2004), uma necessidade basilar é o docente conhecer o ambiente do ciberespaço e sua linguagem, que é a hipermídia, ou linguagens hipermidiáticas. A autora define ciberespaço como:

Um mundo virtual global coerente, independente de como se acede a ele e como se navega nele (p.40) [...] além disso há várias maneiras de se entrar no ciberespaço. Pelas animações sensíveis de imagens no monitor do vídeo 
controlado pelo mouse, passando pela tecnologia da realidade virtual, que visa recriar o sensório humano tão plenamente quanto possível, até os eletrodos neurais diretos. (p. 41) [...] é um sistema de comunicação eletrônica global que reúne os humanos e os computadores em uma relação simbiótica [...] é o espaço que se abre quando o usuário conecta-se com a rede. [...] um espaço feito de circuitos informacionais navegáveis (p. 45). [...] um universo etéreo que se expande indefinidamente mais além da tela, por menor que seja, podendo caber até mesmo na palma de nossa mão (SANTAELLA, 2004, p.46).

Na busca por explicar essa navegação, a autora recorre a uma linguagem metafórica e assevera que, ao navegar nesse "espaço virtual" sem limites, sem fronteiras é como andar mar adentro, sem saber delinear os encontros e desencontros da informação. Por isso, muitas vezes, mistura-se o joio e o trigo, na tentativa de desvendar o que é real do que é manipulado.

Outra definição de ciberespaço encontramos nas pesquisas de Levy (2004), segundo este autor

o ciberespaço (que também chamarei de "rede") é o novo meio de comunicação que surge da interconexão mundial dos computadores. O termo especifica não apenas a infra-estrutura material da comunicação digital, mas também o universo oceânico de informações que ela abriga, assim como os seres humanos que navegam e alimentam esse universo. Quanto ao neologismo "cibercultura", especifica aqui o conjunto de técnicas (materiais e intelectuais), de práticas, de atitudes, de modos de pensamento e de valores que se desenvolvem juntamente com o crescimento do ciberespaço (LEVY, 1999, p. 17).

Assim, é neste espaço, afirma Santaella (2004), que nos deparamos com a linguagem midiática.

A hipermídia mescla textos, imagens fixas e animadas, vídeos, sons, ruídos em um todo complexo. [...] também permite a organização reticular dos fluxos informacionais em arquiteturas hipertextuais [...] sua capacidade de armazenar informação e, por meio da interação do receptor, transmutar-se em incontáveis versões virtuais que vão brotando na medida mesma em que o receptor se coloca em posição de co-autor (SANTAELLA, 2004, p. 48-49). 
Estabelecendo um diálogo entre Santaella (2004) e Chartier (1999), encontramos que esse receptor é denominado por Chartier (1999) como leitor. Esse sujeito leitor é capaz de nos conduzir por outros caminhos em novos tempos, pois ele "é um caçador que percorre terras alheias" (CHARTIER, 1999, p. 77). Essas asserções nos direcionam ao encontro de novas formas de ler, de novos objetos, novas razões, logo, temos a possibilidade de encontrar novos significados. No processo de busca dessa ampliação do olhar, o leitor assume o papel de co-autor, no momento da leitura do texto. Logo, temos um leitor ativo, capaz de acessar seus conhecimentos prévios e construir novos sentidos para o texto.

Os novos leitores, inebriados, deixam-se conduzir por caminhos digitais, midiáticos, onde já não se "rabisca" a borda do livro, mas pode-se interferir, inferir, intervir, alterar o texto do outro na tela do computador.

Cada leitor, para cada uma de suas leituras, em cada circunstância, é singular. Mas esta singularidade é ela própria atravessada por aquilo que faz que este leitor seja semelhante a todos aqueles que pertencem à mesma comunidade (CHARTIER, 1999, p. 91 e 92).

Como pode ser observado, o contexto acima nos aponta que estamos no que Chartier (2002) denomina de "revolução eletrônica". Esta revolução poderia contribuir para aprofundar ainda mais as diferenças sociais, assim como incentivar o surgimento de oposições de leitores: campo/cidade, político/apolítico, patrão/empregado, homem/mulher, bem como identificar as representações, ou seja, as apropriações que cada um faz, visto que elas geram significações diferentes aos mesmos textos, por conseguinte também geram a elaboração de novas leituras.

Então, com o avanço da tecnologia e a disseminação dos processos eletrônicos, caminhamos para mudanças significativas no comportamento do leitor, tanto enquanto pessoa, como também como ser-no-mundo. Isso equivale a dizer que o leitor é um sujeito situado dentro de determinado contexto histórico, em dada situação econômica, inserido na cultura da era da informática e estes fatores influenciam em suas representações. 
A era da informática nos torna mais exigentes, mais egoístas, mais solitários. Esta afirmação nos leva ao texto de Chartier (2002, p. 102-123) sobre a "Morte ou transfiguração do leitor?", onde o sonho, a utopia é pela transfiguração, do latim transfiguratione, que significa passar pela transformação, pela metamorfose, pelos processos de mudanças. Essas asserções nos permitem uma intertextualidade com a letra da música de Raul Seixas: "Prefiro ser essa metamorfose ambulante / Do que ter aquela velha opinião formada sobre tudo". Na era em que nos encontramos essas "verdades absolutas e eternas" já não parecem tão absolutas assim. Um exemplo disso está relacionado ao ato de ler.

A leitura, na era da informática, é uma leitura mais fragmentada, na qual o aluno pode "pular" de link em link. Estes links ora orientam / complementam, as informações, ora as desvirtuam. Esse processo, se não for bem administrado, pode dificultar a competência individual do leitor, sobretudo na seleção do que deve e do que não deve ser lido, podendo haver, inclusive, o risco dele se emaranhar na própria teia e percorrer caminhos não desejados. Numa página de internet, por exemplo, encontra-se muita coisa boa, que pode ser "garimpada", mas nela temos, também, informações que não são relevantes. Resumindo: é preciso aprender a fazer a leitura seletiva.

Com isso, reafirma-se a importância do papel da escola e do professor como mediadores, coordenadores, orientadores, norteadores da leitura, pois a hipermídia, como relata Santaella (2004, p. 50) "não é feita para ser lida do começo ao fim, mas, sim, através de buscas, descobertas, escolhas. Desatando os milhares de nós, encontrando pegadas que o auxilie na formação de um mapa cognitivo".

Sobre essa temática, na voz de Chartier (2002) encontramos uma preocupação com a socialização do saber: a conversão eletrônica de todos os textos. Segundo o autor trata-se de um sonho:

O sonho é sedutor. Mas não deve nos desencaminhar. Em primeiro lugar, é preciso lembrar com insistência que a conversão eletrônica de todos os textos, cuja existência não começa com a informática, não deve absolutamente significar a relegação, o esquecimento ou, o que é pior, a destruição dos manuscritos ou dos impressos que antes Ihes haviam servido de suporte (CHARTIER, 2002, p. 119120). 
Mediante ao exposto, podemos asseverar que há espaço tanto para os textos impressos, via livro, como para os midiáticos. O diferencial é que nestes a socialização do saber permite maior acessibilidade ao conhecimento, independentemente do lugar geográfico, tempo e espaço que o aluno se encontra.

Assim, se estamos falando sobre um sujeito leitor, co-autor do texto, na busca pela construção do seu conhecimento, entendemos que uma instância que pode auxiliar nesse processo é a escola.

Dentro da escola, um caminho possível é via as atividades de leitura e estas podem ser desenvolvidas, de forma direcionada, pelo professor, nas aulas de literatura.

\section{LEITURA, LITERATURA E O PAPEL DO PROFESSOR MEDIADOR}

Silva (2005, p. 16-17) nos diz que leitura e literatura podem parecer duas coisas distintas, sem conexões em sala de aula. Entretanto, estudos indicam que existem investigações / discussões sobre a inter-relação entre ambas, mas parece ser algo que fica só na teoria, não chegando à prática, justamente por isso trata-se de um campo que precisa ser melhor investigado.

Segundo Silva (2005), as relações entre leitura, literatura e teoria literária deveriam ser mais enfatizadas no meio escolar pela "própria natureza interdisciplinar do ato de ler que envolve contribuições de diversas áreas", pelo "fato de a significação do texto literário ser construída a partir da participação efetiva do receptor, o que torna evidente as relações dinâmicas entre a literatura e o leitor" e o fato de "a teoria literária só existir em função da leitura e da literatura".

Soares (apud Silva, 1999, p.17) afirma que existe uma escolarização do texto literário que é adequada, ou seja, a que conduz de forma eficaz a prática da leitura no contexto social, e uma inadequada, que acontece frequentemente em sala de aula e provoca a resistência ou até mesmo aversão do aluno.

Uma leitura literária artificial, mecânica na qual o educando precisa "comprovar" que leu, por meio do preenchimento de uma mera ficha de leitura, é um exemplo de uma atividade que pode afastar 
o aluno do prazer de ler. Sem falar que com a tecnologia, são informações facilmente localizáveis. Além disso, essa proposta de atividade não foge aos padrões, pois pede-se para o aluno citar: obra, autor, personagens, enredo, título, etc. Isso não passa de uma tarefa avaliativa, obrigatória, construindo o mito de que a leitura literária é difícil, subestimando a capacidade interpretativa do aluno e que não desperta o prazer em ler.

Diante disso, o papel do professor mediador é criar um ambiente, provocar, auxiliar no processo das informações, fazer circular as ideias, direcionar esforços para desenvolver atividades capazes de ampliar a visão dos alunos. Trata-se do ato de ler por trás do texto, vinculando esta leitura às aprendizagens que os alunos encontram fora da escola, no uso social da prática da leitura.

Silva (2005, p.21) alerta para que o professor realize a seleção de textos considerando os interesses e a capacidade interpretativa do aluno. "Não encontrando uma relação direta entre o texto literário e o seu cotidiano, o aluno não percebe a literatura como espaço de construção de mundos possíveis que dialogam com a realidade." Apresentar a leitura literária como a "janela para o mundo", na qual o educando poderá encontrar visões de mundo, ideologia de uma época, valores culturais, costumes, enfim uma infinidade de elementos que identificam um outro tempo com muitas questões sócio-econômica-cultural-política-social tal qual a realidade que ele vivência aqui e agora. Trata-se de questões que embora estejam cronologicamente em outro tempo e espaço, socialmente estão presentes na atualidade do leitor.

Esse leitor atual é, justamente, aquele que convive diariamente com a tecnologia. Na escola, o desafio é ver as novas tecnologias a serviço da educação. O sujeito que vai fazer essa mediação é o professor. Logo, é preciso que ele encontre ferramentas que ao mesmo tempo em que elas cativam os alunos para um novo olhar sobre a leitura literária, conduzam a novas experiências, a um novo caminhar, de tal forma que o aluno descubra que é possível ter prazer em ler. Ler, inclusive, os clássicos e, como afirma Calvino (1993, p.13), "os clássicos não são lidos por dever ou por respeito, mas só por amor. Exceto na escola: a escola deve fazer com que você conheça bem ou mal um certo número de clássicos[...]". 
Essa preocupação com a socialização dos clássicos já se faz presente, inclusive, na televisão, no teatro. Temos inúmeras peças e minisséries que são adaptações literárias e muitos arquivos encontram-se ao dispor do professor na mídia.

Para levar esse saber para a sala de aula a TV multimídia ${ }^{1}$ pode ser uma ferramenta adequada. Ela está presente em todas as escolas no estado do Paraná e pode auxiliar no processo de aproximação dos alunos com as obras literárias. Um ponto a favor é, sem dúvida, a riqueza das múltiplas linguagens.

Através da linguagem do cinema, da música, observamos que ao mesmo tempo em que o enredo literário fascina o aluno ele pode ser processo de ensino-aprendizagem. Além disso, já temos exemplos de inúmeros trabalhos que podem ser feitos por professores, em sala de aula, nos quais os educandos, com base nas obras literárias, montam os seus próprios textos e as suas produções cinematográficas.

Tendo como base a leitura, os alunos podem criar novas histórias, dramatizar, filmar e apresentar para a turma. No Youtube encontramos alguns exemplos. O primeiro deles, o trabalho consistiu na leitura de textos a e na representação, gravação em áudio e vídeo e contextualização para a sala. A pesquisa foi desenvolvida numa escola localizada na zona sul de Londrina (PR). Trata-se da dramaturgia da lenda africana intitulada "A viúva velha" ${ }^{2}$. O enredo narra uma triste lenda sobre uma viúva, velha que não tinha filhos e, por magia, as cabaças se transformarem em seus filhos, por um tempo. Em sala foram trabalhadas questões relacionadas aos valores pessoais.

Outro exemplo literário trabalhado em sala de aula encontramos no texto "Quem perde o corpo é a língua" ${ }^{3}$. No enredo temos a narração do encontro de um caçador com uma caveira e, a partir dali, todo um contexto que apresenta a lenda angolana. Esses são apenas dois dos muitos exemplos existentes no qual é possível quebrar um tabu: o aluno ter acesso à literatura e ter voz.

\footnotetext{
${ }^{1}$ TV Multimídia, também conhecida como TV pen drive, são televisores com entradas para VHS, DVD, cartão de memória e pen-drive, além de saídas para caixas de som e projetor multimídia, que estão presentes nas 22 mil salas de aula da rede estadual de educação do Paraná.

${ }^{2} \mathrm{O}$ texto pode ser lido, na íntegra, em <http://sonhosebonecos.blogspot.com.br/2010/03/viuva-velha.html> e o vídeo encontra-se em <http://www.youtube.com/watch?v=XwXEsiBeBKI>.

${ }^{3} \mathrm{O}$ texto pode ser lido, na íntegra, em < http://eraumavez-ademar.blogspot.com.br/2009/09/quem-perde-o-corpo-elingua.html> e o vídeo encontra-se em <http://www.youtube.com/watch?v=boFuSduXOPE $>$.
} 
Silva (1999, p.55) nos lembra que as vozes dos alunos merecem ser ouvidas na leitura de poemas, contos, crônicas, romances, dramas. Conversando sobre a diversidade de textos e gêneros literários motivar para a criação, a produção. A montagem de um blog, de um mural na escola, uma página de discussão no Facebook, e quem sabe chegar a uma criação coletiva de um texto eletrônico.

Em Levy (1999, p.56), vemos que a noção de texto virtual vem revolucionando a concepção de uma autoria compartilhada, entendendo-se o hipertexto como "um texto móvel, caleidoscópio, que apresenta suas facetas, gira, dobra-se e desdobra-se à vontade frente ao leitor". Essa forma de ver o texto e navegar incansavelmente por ele "encanta" o leitor despertando uma paixão estonteante pela leitura, pois "no universo infinito da literatura sempre se abrem outros caminhos a explorar, novíssimos ou antigos, estilos e formas que podem mudar nossa imagem de mundo" (CALVINO,1990, p.20), e o papel sublime do professor mediador é provocar e proporcionar condições para a mudança.

\section{CONSIDERAÇÕES FINAIS}

O objetivo do presente artigo foi estabelecer um diálogo entre a hipermídia e o ensino de literatura na escola. Para construir essa ponte, optamos por trilhar um caminho. Iniciamos apontando para a necessidade de, na atualidade, o professor desenvolver, no educando, a competência tecnológica, pois desta forma ele estará o preparado para a sua vida junto à sociedade.

A questão do desenvolvimento adequado da competência tecnológica perpassa pela questão da educação com qualidade. Com isso, necessário se fez dialogarmos sobre os conceitos de comportamento, competência, desenvolvimento de habilidades e, sobretudo, sobre a necessidade de se aprender (a conhecer, a fazer, a conviver e a ser).

Nesse processo de aprendizagem entra a mediação do professor, visto ser ele o mediador entre o aluno e o conhecimento. Então, para que esse sujeito possa auxiliar o educando na interação com 
esse novo contexto tecnológico que já se instaurou, necessário se faz este docente estar preparado.

Neste sentido, de acordo com o recorte que optamos para este artigo, enfocamos a questão da mediação do professor no contexto atual. Consideramos que um dos problemas apontados nos exames governamentais está relacionado à dificuldade de leitura do aluno na escola.

Visando vir ao encontro dessa problemática, nossa proposta foi de um trabalho interligado entre o uso das hipermídias na escola e o ensino de literatura. Sedimentados nas experiências reais que apresentamos, realizadas numa escola de Londrina, asseveramos que a literatura, em conjunto com as ferramentas midiáticas, são um instrumento eficaz, pois permite ao professor trabalhar, juntamente com o aluno, a leitura e a oralidade. Outro ponto relevante é a dessacralização dos clássicos, ou seja, de obras bem guardadas e de acesso restrito eles passam a ser um saber democratizado, socializado. Entendemos ser essa uma faz funções da literatura na escola: fazer com que o aluno tenha acesso a ela para que ele possa pensar as grandes questões da sua vida, pois todas estão presentes, de certa forma, nas diversificadas obras literárias. 


\section{REFERÊNCIAS}

BIDERMAN, Maria Tereza Camargo. Dicionário Didático de Português. 2ạ ed. São Paulo: Editora Ática, 1998.

CHARTIER, Roger. A aventura do livro - do leitor ao navegador. Unesp. SP: 1999.

CHARTIER, Roger. Os desafios da Escrita. Unesp. SP: 2002 (p. 101-123).

DELORS, J. Educação: um tesouro a descobrir. Disponível em: <http://unesdoc.unesco.org/images/0010/001095/109590por.pdf>. Acesso em 10 ago 2013.

CALVINO, I. Seis propostas para o próximo milênio. São Paulo: Companhia das Letras, 1990.

DICIONÁRIO Aurélio do Século XXI (online). Disponível em:

$<$ http://www.dicionariodoaurelio.com>. Acesso em 09/08/2013.

GARDNER, Howard. Inteligências múltiplas: a teoria na prática. Trad. Maria Adriana Veríssimo Veronesse, Porto Alegre: Artes Médicas, 1995.

HOBSBAWN, Eric. Era dos Extremos - O breve século XX (1914-1991). São Paulo: Companhia das Letras, 1995.

LÉVY, Pierre. Cibercultura. Trad. Carlos Irineu da Costa. Rio de Janeiro: Editora 34, 1999.

LEVY, P. As tecnologias da inteligência: o futuro do pensamento na era da informática. Rio de Janeiro: Ed. 34, 2006.

MELLO, Ana Virgínia Chaves; ARAUJO, Eliany Alvarenga. Competência Informacional e gestão do conhecimento: uma relação necessária no contexto da sociedade da informação. MG: Revista Perspectivas em ciências da Informação. V. 12, no 2, P. 185-201, maio-ago, 2007.

MENEZES, E.T.; SANTOS, T. H. "Competência" (verbete). Dicionário Interativo da Educação Brasileira - EducaBrasil. São Paulo: Midiamix Editora, 2002, http://www.educabrasil.com.br/eb/dic/dicionario.asp?id=56>. Acesso em: 18 ago 2013.

MIRANDA, 2004, p. 113

MORAN, José Manuel. Novas tecnologias em mediação pedagógica. 19ạ edição. Campinas, SP:

Papirus, 2012.

PERRENOUD, Philippe. Dez competências para ensinar: convite à viagem. Porto Alegre: Artes Médicas Sul, 2000,

SANTOMAURO, B. A alfabetização do nosso tempo. Revista Nova Escola, São Paulo: Editora Abril, 2013, p. 46-57.

ROESLER, Jucimara; FLORES, Angelita; COSTA, André. Prática docente e novas tecnologias: livro didático. Palhoça: UNISULVirtual, 2005.

SANTOMAURO, Beatriz. A alfabetização do nosso tempo. SP: Ed. Abril. Revista Nova Escola, ago 2013, p. 46-54.

SANTAELLA, Lucia. Navegar no Ciberespaço: o perfil cognitivo do leitor imersivo. São Paulo: Paulus, 2004.

SEIXAS, Raul. Metamorfose ambulante. Disponível em: <http://www.raulseixas.com.br/frame letras.htm> Acesso em: 6 jul 2013. 
SILVA, Ivanda M.M. Literatura em Sala de aula: da teoria literária a prática escolar. Recife: Programa de Pós-Graduação da UFPE, 2005.

SILVA, Lindalva de Freitas. As tecnologias educacionais no contexto de trabalho e suas implicações na prática pedagógica. Anais Eletrônicos 2은 Simpósio Hipertexto e Tecnologias na Educação. Universidade Federal de Pernambuco, 1a Edição, 2008. Disponível em:

<http://www.ufpe.br/nehte/simposio2008/anais/Lindalva-Freitas-Silva.pdf>

SOARES, M. A escolarização da literatura infantil e juvenil. In: EVANGELISTA, Aracy et al. (orgs.).

Escolarização da leitura literária. Belo Horizonte: Autêntica, 1999, p.17-48. 